\title{
Biological invasion at an early stage? First record of the banjo catfish Pseudobunocephalus iheringii (Siluriformes: Aspredinidae) in the Tramandaí river basin, Brazil and the potential invasion pathway to this system
}

\author{
R. A. Silveira ${ }^{a}$, J. Ferrer ${ }^{b}$, F. G. Becker ${ }^{a}$ and S. M. Hartz ${ }^{a}$ \\ aprograma de Pós-graduação em Ecologia, Departamento de Ecologia, Universidade Federal do Rio Grande do Sul - \\ UFRGS, Av. Bento Gonçalves, 9500, Prédio 43422, Sala 102, CP 15007, CEP 91501-970, Porto Alegre, RS, Brazil \\ bPrograma de Pós-graduação em Biologia Animal, Departamento de Zoologia, Universidade Federal do Rio Grande \\ do Sul - UFRGS, Av. Bento Gonçalves, 9500, Prédio 43435, CEP 91501-970, Porto Alegre, RS, Brazil \\ *e-mail: silveirara@hotmail.com
}

Received: February 5, 2016 - Accepted: June 16, 2016 - Distributed: November 31, 2017

(With 1 figure)

Biological invasion by species that are not naturally present in a native assemblage (nonnative species) is a multi-stage process (Blackburn et al., 2011). However, perception of an invasive process is difficult in early stages of the process, when abundance is very low and distribution is very limited. Understanding biological invasions and, eventually, taking management measures to prevent them, depends on early detection of the invasion process (Kolar and Lodge 2001).

The presence of nonnative fish species has been reported in the Tramandaí river basin (Schifino et al., 2004; Artioli and Maia 2010; Artioli et al., 2013), but their introduction pathway in the Tramandaí river basin is unknown. A plausible possibility points to the artificial water channels in the wetlands and rice fields at the watershed divide between the Laguna dos Patos basin and the Tramandaí river basin.

The aim of this paper is to report the occurrence of Pseudobunocephalus iheringii (Boulenger 1891) in an artificial channel in the watershed divide between the Laguna dos Patos basin and the Tramandaí river basin, in southern Brazil. This report represents the first record of an additional nonnative species in the Tramandaí basin, documents the early stage of a potential invasion process in this system, and represents the first evidence for the role of artificial water channels as invasion pathways for nonnative fish species into the Tramandaí basin, affecting two aquatic ecoregions (Laguna dos Patos and Tramandaí-Mampituba; Abell et al., 2008).

The Tramandaí river basin is a coastal hydrographic system located in Rio Grande do Sul, Brazil. The system includes 41 lakes with different degrees of interconnection and communicates with the sea only through the estuary of Tramandaí (Guimarães et al., 2014). In terms of fish fauna, the Tramandaí river system has about 100 species of freshwater fish, not counting the estuarine and marine species that use the estuary of Tramandaí to complete their life cycle (Malabarba et al., 2013). Between June and August of 2015, 19 channels that interconnect the lakes of the Tramandaí river system were sampled with seine nets and dip nets to investigate the fish community composition, ranging from the most northern lagoon to the most southern lagoon and also one artificial channel that links the Tramandaí river basin to the Laguna dos Patos basin (Figure 1A).

A total of 47 species and 1244 individuals were recorded at the 19 channels, and 9 species and 62 individuals at the artificial channel. All of them were native or previously reported nonnative species, except for three individuals of Pseudobunocephalus iheringii (Figure1B) - readily diagnosed according to the revision provided by Friel (2008) - captured with seine net in the sample site located at an artificial channel ( $30^{\circ} 11^{\prime} 14.9$ 'S and $\left.50^{\circ} 22^{\prime} 1.07^{\prime \prime} \mathrm{W}\right)$. All specimens were deposited at the UFRGS ichthyological collection (UFRGS 20672, Figure 1B).

This record of $P$. iheringii documents the early stage of a new nonnative fish invasion in the Tramandaí River system. Firstly, because the natural occurrence of this species in the Tramandaí river basin is implausible. Although $P$. iheringii is widely distributed in the Paraguay-Paraná, Uruguay and Laguna dos Patos basins (Friel, 2008) it had never been previously recorded at the Tramandaí basin, despite large sampling effort since the 1980 decade (Malabarba and Isaia, 1992; Ramos and Vieira, 2001; Schifino et al., 2004; Rocha and Hartz, 2013; Malabarba et al., 2013; Guimarães et al., 2014). Additionaly, recent inventories of fish communities have recorded $P$. iheringii in the Laguna dos Patos system just next to the inter-basin connection with the Tramandaí system (in lake Casamento and neighboring wetlands; Becker et al., 2007), but not in the Tramandaí system, despite widespread sampling (Guimarães et al., 2014) and historical fish composition reviews (Malabarba and Isaia, 1992; Malabarba et al., 2013). Second, because there are no current physical or mechanic barriers between the sample site at the artificial channel connecting the Casamento lake (in Laguna dos Patos basin) and the Fortaleza lake (Tramandaí river basin). 


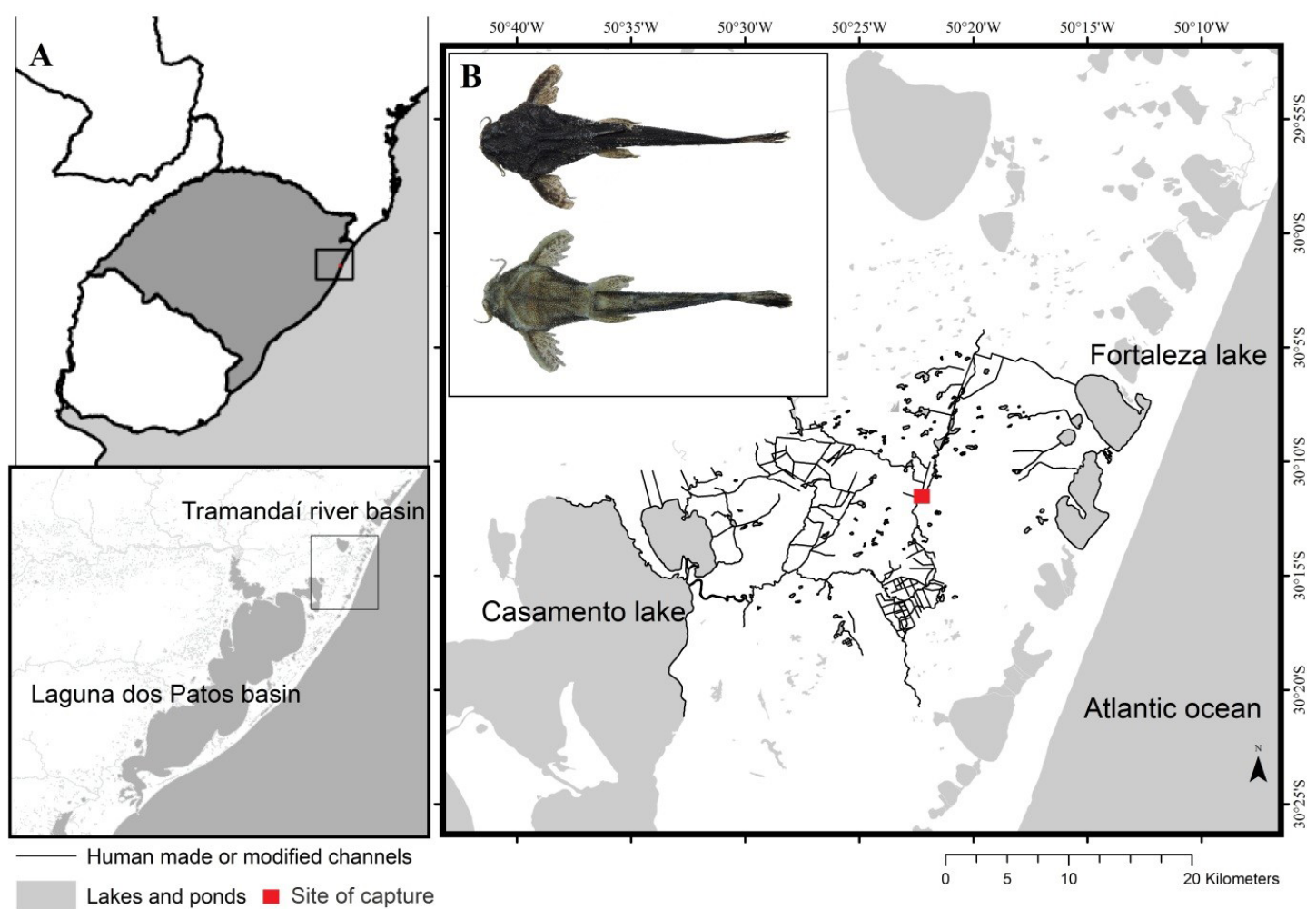

Figure 1. (A) Map showing the sample unit where the three specimens of Pseudobunocephalus iheringii were collected; (B) The dorsal and ventral views of one individual of $P$. iheringii (UFRGS 20672, SL =30.94 mm).

We argue that the absence of previous records in the Tramandaí river basin and the current establishment of artificial channels connecting the Laguna dos Patos and Tramandaí basin corroborate the hypothesis that this area may be the invasion pathway not only for $P$. iheringii, but probably for other previously recorded invasive species (Schifino et al., 2004; Artioli and Maia, 2010; Artioli et al., 2013). This inter-basin connection has been facilitated by local landscape characteristics, such as low terrain and large wetland areas, which allowed the development of rice fields and their associated network of artificial water channels (Becker et al., 2007), increasing the connectivity between two aquatic ecoregions (the Laguna dos Patos and Tramandaí-Mampituba).

\section{References}

ABELL, R., THIEME, M.L., REVENGA, C., BRYER, M., KOTTELAT, M., BOGUTSKAYA, N., COAD, B., MANDRAK, N., BALDERAS, S.C., BUSSING, W., STIASSNY, M.L.J., SKELTON, P., ALLEN, G.R., UNMACK, P., NASEKA, A., NG, R., SINDORF, N., ROBERTSON, J., ARMIJO, E., HIGGINS, J.V., HEIBEL, T.J., WIKRAMANAYAKE, E., OLSON, D., LÓPEZ, H.L., REIS, R.E., LUNDBERG, J.G., SABAJ PÉREZ, M.H. and PETRY, P., 2008. Freshwater ecoregions of the world: a new map of biogeographic units for freshwater biodiversity conservation. Bioscience, vol. 58, no. 5, pp. 403-414. http:// dx.doi.org/10.1641/B580507.
ARTIOLI, L.G.S., CARVALHO NETO, P., MAIA, R. \& FIALHO, C.B., 2013. First record of the non-native species Acestrorhynchus pantaneiro Menezes, 1992 (Characiformes, Acestrorhynchidae) in the Tramandaí River system, Rio Grande do Sul, Brazil. Pan-American Journal of Aquatic Sciences, vol. 8, no. 1, pp. 51-54.

ARTIOLI, L.G.S. and MAIA, R., 2010. Pisces, Siluriformes, Auchenipteridae, Trachelyopterus lucenai Bertoletti, Pezzi da Silva \& Pereira, 1995: historical occurrence and distribution extension. Check List: Journal of Species Lists and Distribution, vol. 6, no. 4, pp. 515-516. http://dx.doi.org/10.15560/6.4.515.

BECKER, F.G., GROSSER, K.M., MILANI, P.C. and BRAUN, A.S., 2007. Peixes. In: F.G. BECKER, L.A. MOURA and R.A. RAMOS, orgs. Biodiversidade. Regiões da Lagoa do Casamento e dos Butiazais de Tapes, Planície Costeira do Rio Grande do Sul. Brasilia: Ministério do Meio Ambiente, cap. 19, pp. 262-275.

BLACKBURN, T.M., PYSEK, P., BACHER, S., CARLTON, J., DUNCAN, R.P., JAROSIK, V., WILSON, J.R.U. and RICHARDSON, D.M., 2011. A proposed unified framework for biological invasions. Trends in Ecology \& Evolution, vol. 26, no. 7, pp. 333-339. PMid:21601306. http://dx.doi.org/10.1016/j. tree.2011.03.023.

FRIEL, J.P., 2008. Pseudobunocephalus, a new genus of banjo catfish with the description of a new species from the Orinoco River system of Colombia and Venezuela (Siluriformes: Aspredinidae). Neotropical Ichthyology, vol. 6, no. 3, pp. 293-300. http://dx.doi. org/10.1590/S1679-62252008000300001. 
GUIMARÃES, T.F.R., HARTZ, S.M. and BECKER, F.G., 2014. Lake connectivity and fish species richness in southern Brazilian coastal lakes. Hydrobiologia, vol. 740, no. 1, pp. 207. http:// dx.doi.org/10.1007/s10750-014-1954-x.

KOLAR, C.S. and LODGE, D.M., 2001. Progress in invasion biology: predicting invaders. Trends in Ecology \& Evolution, vol. 16, no. 4, pp. 199-204. PMid:11245943. http://dx.doi.org/10.1016/ S0169-5347(01)02101-2.

MALABARBA, L.R., CARVALHO NETO, P., BERTACO, V.A., CARVALHO, T.P., FERRER, J. and ARTIOLI, L.G.S., 2013. Guia de identificação dos peixes da bacia do rio Tramandaí. Porto Alegre: Ed. Via Sapiens.

MALABARBA, L.R. and ISAIA, E.A., 1992. The freshwater fish fauna of the rio Tramandaí drainage, Rio Grande do Sul, Brazil, with a discussion of its historial origin. Comunicações do Museu de Ciências da PUCRS, vol. 5, pp. 197-223.

RAMOS, L.A. and VIEIRA, J.P., 2001. Composição específica e abundância de peixes de zonas rasas dos cinco estuários do Rio Grande do Sul, Brasil. Boletim do Instituto de Pesca, vol. 27, no. 1, pp. 109-121.

ROCHA, E.A. and HARTZ, S.M., 2013. Estabilidade e persistência de uma comunidade de peixes em lagoa costeira neotropical. Revista Brasileira de Biociências, vol. 11, no. 2, pp. 149-156.

SCHIFINO, L.C., FIALHO, C.B. and VERANI, J.R., 2004. Fish community composition, seasonality and abundance in Fortaleza lagoon, Cidreira. Brazilian Archives of Biology and Technology, vol. 47, no. 5, pp. 755-763. http://dx.doi.org/10.1590/S151689132004000500011. 